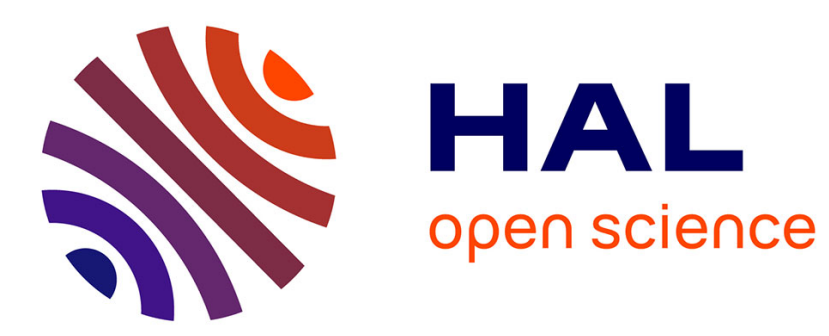

\title{
CREEP BEHAVIOR OF ZIRCONIA FOAMS USED IN ELECTRICAL FURNACES (2100 K - AIR)
}

\author{
F. Cabannes, K. Dembinski, y . Bigay
}

\section{To cite this version:}

F. Cabannes, K. Dembinski, y . Bigay. CREEP BEHAVIOR OF ZIRCONIA FOAMS USED IN ELECTRICAL FURNACES (2100 K - AIR). Journal de Physique Colloques, 1986, 47 (C1), pp.C1649-C1-654. 10.1051/jphyscol:1986199 . jpa-00225630

\section{HAL Id: jpa-00225630 https://hal.science/jpa-00225630}

Submitted on 1 Jan 1986

HAL is a multi-disciplinary open access archive for the deposit and dissemination of scientific research documents, whether they are published or not. The documents may come from teaching and research institutions in France or abroad, or from public or private research centers.
L'archive ouverte pluridisciplinaire HAL, est destinée au dépôt et à la diffusion de documents scientifiques de niveau recherche, publiés ou non, émanant des établissements d'enseignement et de recherche français ou étrangers, des laboratoires publics ou privés. 


\title{
CREEP BEHAVIOR OF ZIRCONIA FOAMS USED IN ELECTRICAL FURNACES (2100 K - AIR)
}

\author{
F. CABANNES, K. DEMBINSKI and Y. BIGAY* \\ Université, C.N.R.S., C.R.P.H.T., ID Avenue de la Recherche \\ Scientifique, F-45071 Orléans Cedex 2, France \\ "Céramiques Techniques DESMARQUEST, 2 Avenue Albert Einstein, \\ F-78193 Trappes Cedex, France
}

\begin{abstract}
Résumé - Des mousses de zircone-chaux sont utilisées comme élément chauffant dans des fours électriques. On a examiné leur comportement au fluage à haute température et sous faible contrainte qui conditionne leur utilisation. D'importants effets visco-élastiques ont été observés. On pense qu'ils sont attribuables à une recristallisation, associée à la transition de phase quadratique-cubique et sensible à la contrainte.
\end{abstract}

\begin{abstract}
Some zirconia foams are used as heating element in electrical furnaces. Their creep behaviour has been investigated at high temperature and under low stress. Important visco-elastic behaviour has been observed. It is likely due to recrystallization, which is sensitive to the tetragonal-cubic phase transition and to the stress.
\end{abstract}

\section{I - INTRODUCTION}

Porous and dense zirconia based ceramics have been used for several years as heating element in electrical furnace $/ 1$. The so-called zirconia furnace can be operated in air at $2100 \mathrm{~K}$, for long periodes. The aim of the present study is to investigate the creep behaviour of some new zirconia porous ceramics, such as zirconia foams ( ${ }^{1}$ ) which are suitable as heating element. During the seventies, large grain dense ceramics (called ZGM) were used. More recently, porous ceramics made in Japan were prefered according to their thermal shock resistance, but their rough and inhomogeneous microstructure enhanced their brittleness. New materials were made by foam processing. They are much more homogeneous. The porosity lies in the range $0.25-0.71$, so that it is very convenient to choose the electrical resistance and the thermal conductivity of the different parts of the heater (usually, three parts).

\section{IĨ - ELECTRICAL RESISTANCE}

First of all, the electrical resistance of the zirconia foams was measured to check that they can be used as heater. The sample was an hollow cylinder: $20 \mathrm{~mm}$ inner

( $\left.{ }^{1}\right)$ Produced by Ceramiques Techniques Desmarquest. 
diameter, $31 \mathrm{~mm}$ outer diameter, $46.5 \mathrm{~mm}$ length. It was heated by a.c. current, and it has the same behaviour as a heater in the furnace. By this way one obtains the electrical resistance, or at least an average resistivity. The temperature is not uniform through a section of the sample, the temperature gradient can reach $180 \mathrm{~K}$ between the inner and the outer surface.

The figure 1 shows the experimental data. The activation energy is $1.2 \mathrm{eV}$, which is in good agreement with known values $/ 2 /$. The electrical resistance roughly increases as the porosity increases from 0.29 to 0.71 . Compared to the dense zirconia previously used, the electrical properties of the foams are suitable.

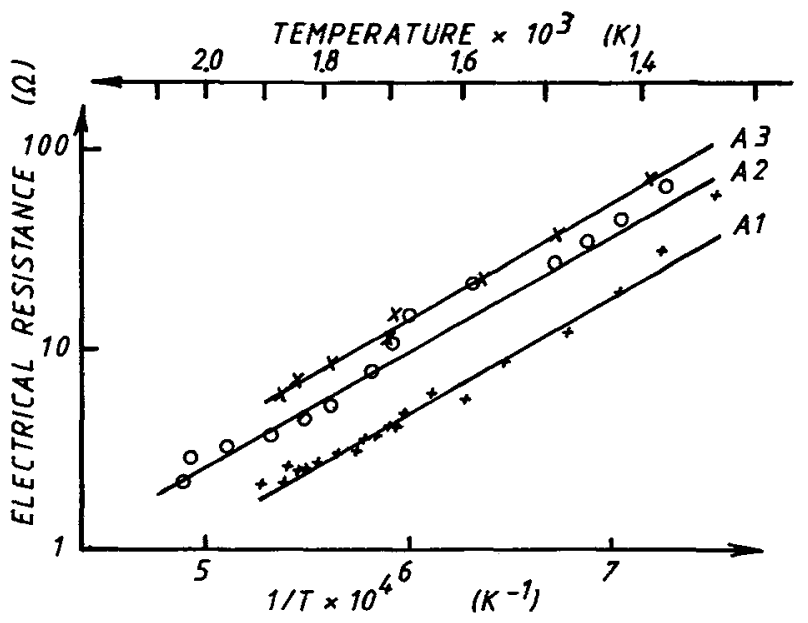

Fig. 1 - Electrical resistance of three zirconia foams (samples A).

\section{III - CREEP MEASUREMENT}

Compression creep has been investigated at fixed temperature under constant stress. The sample sizes were $8 \mathrm{~mm}$ diameter, $15 \mathrm{~mm}$ height. The composition and porosity are given in Table $I$.

Table I - Sample details.

\begin{tabular}{|c|c|c|c|c|c|c|c|}
\hline & $\mathrm{ZrO}_{2}$ & \multicolumn{2}{|c|}{ Chemical composition, weight $\%$} \\
\hline $\mathrm{CaO}$ & $\mathrm{Al}_{2} \mathrm{O}_{3}$ & $\mathrm{MgO}$ & $\mathrm{SiO}_{2}$ & $\mathrm{Fe}_{2} \mathrm{O}_{3}, \mathrm{TiO}_{2}$ & Porosity, $\%$ \\
\hline $\mathrm{A} 1$ & 91 & 3.9 & 3.65 & 0.7 & 0.6 & 0.1 & 29 \\
$\mathrm{~A} 2$ & 91 & 3.9 & 3.65 & 0.7 & 0.6 & 0.1 & 53 \\
& 91 & 3.9 & 3.65 & 0.7 & 0.6 & 0.1 & 71 \\
$\mathrm{B1}$ & 91 & 4.3 & 3.25 & 0.7 & 0.6 & 0.1 & 25 \\
\hline
\end{tabular}

The application of zirconia foams in electrical furnaces involves the high temperature - low stress creep behaviour, in the temperature range $1500-2100 \mathrm{k}$, and at stress level lower than $2.0 \mathrm{MPa}$.

The creep curves show transient creep followed by stationnary creep. Figure $2 a$ shows the stationnary creep rate as a function of the stress, at $1773 \mathrm{~K}$ for the samples A. It is likely stress power law, with the exponent $\mathrm{n}=1.75$ to 2.0 . In figure $2 \mathrm{~b}$ are given the data for sample $\mathrm{B}$, between 1850 and $1950 \mathrm{~K}$, a lower value 
of $n=1.3$ is found. We should note that the precision of the stationnary creep rate data is rather low, due to the. influence of the transient creep and some visco-elastic behaviour which is observed, as described in the following section. The value of $n$ indicates that the creep can be controlled by diffusion and grain sliding. A very important grain sliding is observed on the creep fractured samples. This is not surprising since the porosity is high. As a comparison, creep data of ZGM are given on figure 2. The zirconia foams exhibit higher creep resistance than the dense $\mathrm{ZGM}$, in which there is probably a larger amount of silica.

(a)
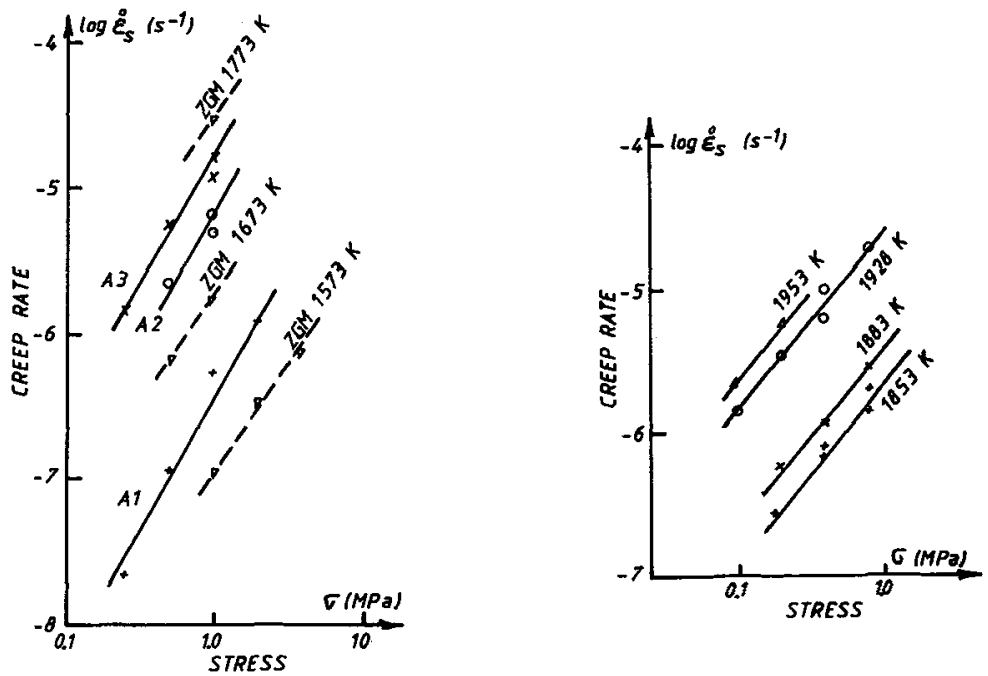

Fig. 2 - Stationnary creep rate as a function of stress. (a) samples A, at $1773 \mathrm{~K}$. (b) sample B, between 1850 and $1950 \mathrm{~K}$. Creep rate of ZGM is given as a comparison.

On figure 3 are plotted the creep rate versus temperature at a stress equal to $1.0 \mathrm{MPa}$. An activation energy of around $180 \mathrm{kcal} / \mathrm{mole}$ is found, which is larger than the value found for dense zirconia.

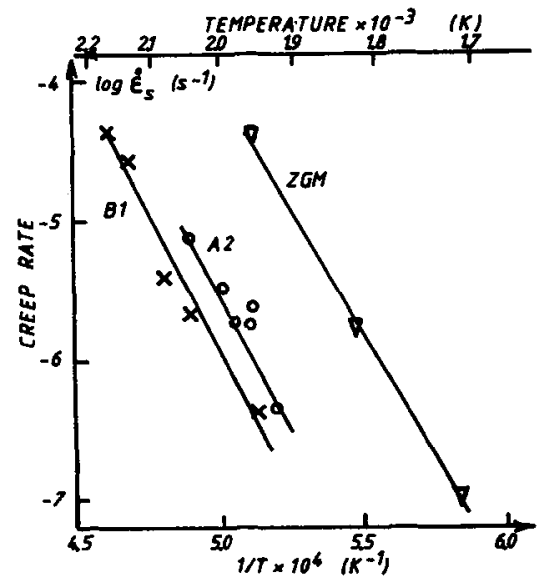

Fig. 3 - Arrhenius plot of the stationnary creep rate.

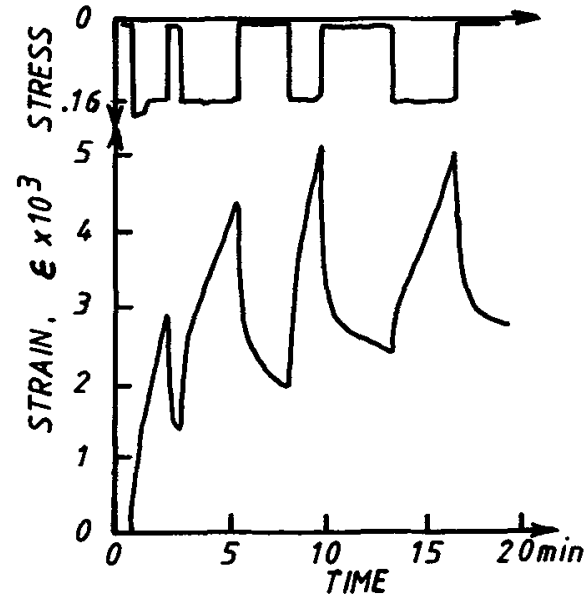

Fig. 4 - Visco-elastic behavior of sample A2 under cyclic stress. Upper: stress versus time, Lower: strain versus time. 


\section{IV - VISCO-ELASTIC BEHAVIOUR}

At high temperature, for instance between 1750 and $1950 \mathrm{~K}$, the zirconia foams exhibit a visco-elastic behaviour with very large strain. The same behaviour has been observed in dense ZGM samples above $1600 \mathrm{~K}$. Figure 4 illustrates such a typical behaviour, under cyclic stress at $1973 \mathrm{~K}$. The sample was already strained at $1.810^{-2}$. Under load there is a transient creep, and when the sample is unloaded it appears a very important visco-elastic effect. The test was stopped because the last loading showed a tertiary creep, however the next unloading does not show a large permanent strain. The time constant of the effect is large : 1 to 10 minutes, and it is of the same order of magnitude than the last of the preceeding creep. The visco-elastic behaviour appears more or less each time the stress value changes. The figure 5 gives an other illustration. In phase I, a transient creep is observed, followed by a stationnary creep, more or less visible. In phase II, the stress was increased, no transient creep is seen. In phase III, a visco-elastic effect appears, as a creep rate which is zero at first and which increases to the stationnary creep rate corresponding to the value of the stress. In phase IV, the stress is very low and the same behaviour as described before is observed. In phase $V$, the transient creep is seen again.

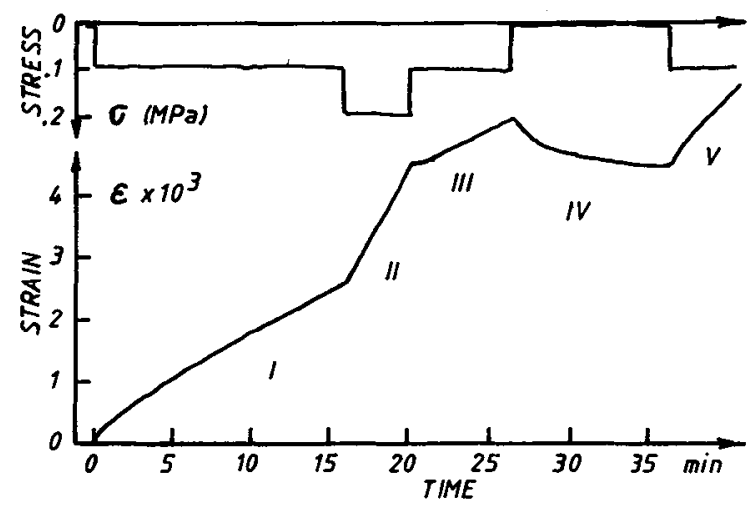

Fig. 5 - Creep curve and visco-elastic effects depending of loading and unloading.

\section{$V-\underline{\text { DISCUSSION }}$}

The temperature range at which the creep was studied corresponds to operating temperature of the zirconia furnace. This is the two-phase domain of the 4 w calcia-zirconia (tetragonal-cubic). The microstructure of crept and uncrept samples were observed (figures $6 \mathrm{a}, \mathrm{b}, \mathrm{c}$ and $\mathrm{d}$ ).

After tertiary creep a large number of cracks appears (see figures 6 a and b). All the cracks are filled by small crystals, as seen on figure $6 \mathrm{c}$, so the recrystallisation seems to be the principal factor for the tertiary creep and the creep fracture of these samples. The recrystallisation can start anywhere as seen in figure $6 \mathrm{~d}$. The presence of alumina in the ceramics could be responsible for the recristallisation. The formation of calcium-aluminate can destabilize the zirconia /3/ however, all the grains which appear are zirconia and no aluminum is observed preferentialy by EXAF on these grains and elsewhere. Moreover the creep resistance of the samples is high, even at $1950 \mathrm{~K}$, thus it does not seem that a liquidus can be formed at this temperature as the phase diagram of calcia-alumina predicts it. The role of the stress during the recrystallisation and eventually the tetragonal-cubic phase transition is not clear at the present time.

The cracking of the samples is not necessarily dangerous for the application of the 


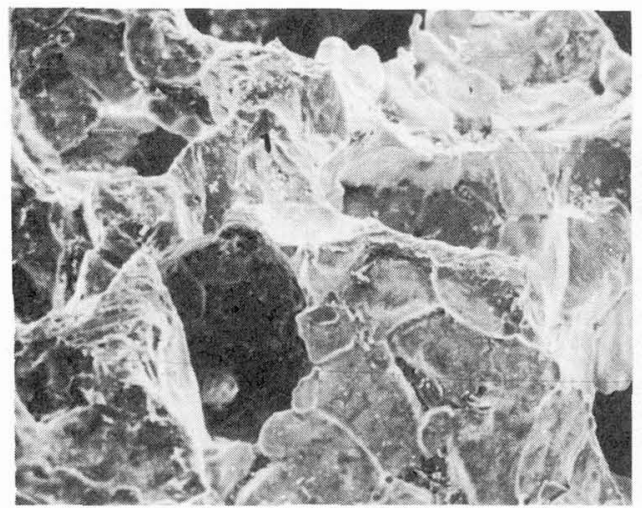

(a)

100 um

Fig. 6 - Microstructures zirconia foam

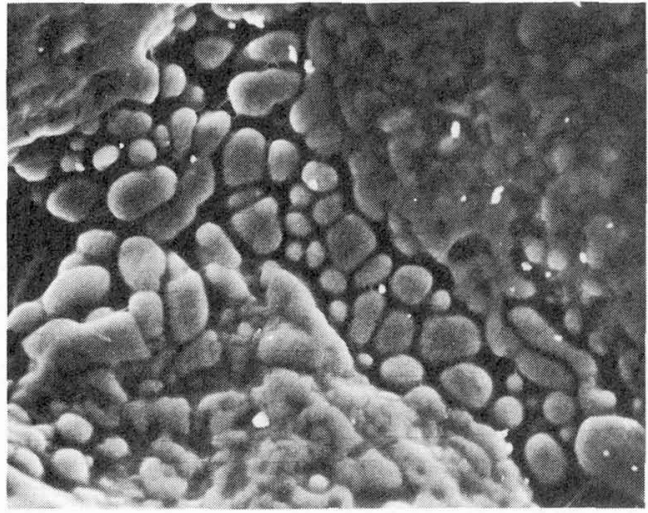

(c)

20 um

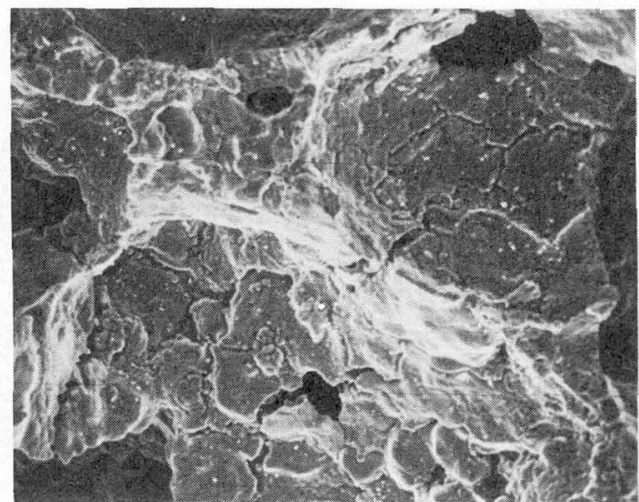

(b)

100 um

(a) uncrept sample A3, (b) crept sample A3.

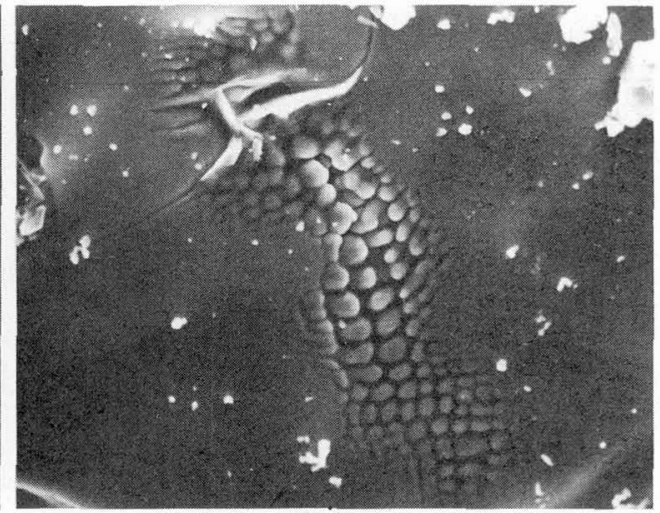

(d)

20 um

Fig. 6 - Microstructure of zirconia foams. (c) recrystallisation observed in the cracks, (d) the recrystallisation can begin anywhere in the grain.

foams, whenever the thermal shock resistance should good and the loading of the samples is very low. However the cracks can have an influence on the electrical resistance of the heater, and it is observed that the resistance of a heater increases slowly when the furnace is operated a very long time.

\section{VI - CONCLUSION}

Zirconia foams are suitable as materials for heating element in electrical furnace. Their electrical properties are convenient and also their creep resistance at high temperature and under low stress. During the creep measurements, important visco-elastic behaviour was observed, which seems to be related to a recrystallisation, and it would be associated to the tetragonal-cubic phase transition and to the stress level. The influence of the stress on the recrystallisation and the formation of cracks should be clarified by further investigation. 


\section{REFERENCES}

/1/ FAUCHER, M., DEMBINSKI, K. and ANTHONY, A.M., Amer. Ceram. Soc. Bull. 49 (1970) 707.

/2/ HARTMANOVA, M., HANIC, F. and KOLLER, A., Materials Science II/3 (1976) 79.

/3/ KOSMAC, T., KOLAR, D. and TRONTELJ, M., in Science and Technology of Zirconia II, p. 546, Amer. Ceram. Soc. Publ. (1984). 